\title{
A trend of increasing burned areas in Iraq from 2001 to 2019
}

\author{
Azad Rasul $^{1}$ (D) Gaylan R. Faqe Ibrahim ${ }^{1,2} \cdot$ Hasan M. Hameed ${ }^{3} \cdot$ Kevin Tansey $^{4,5}$
}

Received: 19 February 2020 / Accepted: 22 June 2020 / Published online: 30 June 2020

(c) The Author(s) 2020

\begin{abstract}
Wildfires have an important role in the ecological process affecting ecosystems at multiple spatial scales. MCD64A1 $500 \mathrm{~m}$ burned area product is used in this study to document trends of fire events from 2001 to 2019. The research aims to analyze the trend of burned areas in the country. Iraq is selected as study area of the research because of dramatically increasing the number of fires in the country. The study found that the lowest amount of burned areas were located in the center and southwest, while northeast and north faced most of the fires. The trend of burned areas in Iraq was an increase of $71.7 \mathrm{~km}^{2}$ per year, and, principally, in the last years, burned areas increased by $1363 \mathrm{~km}^{2}$. The most extensive burning areas occurred in the Ninawa Governorate (29\%). In 2019, burned areas increased to around eight times compared to the yearly average. During 2019, one of the highest classes which contain burned area is "Cropland, rainfed" with $4366 \mathrm{~km}^{2}$ burned. High maximum air temperature and wind speed are the main factors that contribute to increasing burned areas; however, high precipitation and air pressure lead to a reducing amount of burned areas. The rapid increase of fires in the country as a result of burn crop field residues will lead to worsening air pollution and likely decrease forest area in the future.
\end{abstract}

Keywords Fire · Iraqi Governorates · Land cover · MODIS · Remote sensing · Slope · Wildfire

Azad Rasul

azad.rasul@soran.edu.iq

Kevin Tansey

kjt7@le.ac.uk

Gaylan R. Faqe Ibrahim gailan.faqe@ soran.edu.iq

Hasan M. Hameed hasan.hamid@soran.edu.iq

1 Department of Geography, Faculty of Arts, Soran University, Soran 44008, Iraq

2 Department of Geography, College of Humane Sciences, University of Halabja, Halabja, Iraq

3 Department of Civil Engineering, Faculty of Engineering, Soran University, Soran 44008, Iraq

4 Centre for Landscape and Climate Research, School of Geography, Geology and the Environment, University of Leicester, Leicester LE1 7RH, UK

5 National Centre for Earth Observation, University of Leicester, Leicester LE1 7RH, UK 


\section{Introduction}

Wildfires have an important role in the ecological process affecting ecosystems at multiple spatial scales. Recent research has concluded that wildfires have become larger in the world over the last decades (Miller and Safford 2012). The burned area could lead to the demolition of vegetation cover with effects on hydrological processes, plant composition and soil erosion (Lasko 2019). Wildfires release numerous particles and an enormous number of greenhouse gasses such as carbon dioxide $\left(\mathrm{CO}_{2}\right)$, carbon monoxide $(\mathrm{CO})$, coarse $\left(\mathrm{PM}_{10}\right)$, fine-particulate matter (PM). Estimating the burned area is the most important criterion that is utilized to calculate biomass destroyed in wildfire (Andela and Van Der Werf 2014). The carbon monoxide released to the atmosphere about $32 \%$ from burned biomass areas, and the carbon dioxide is around $40 \%$. This situation leads to worsening global warming (Pathfinder 2007).

Burned area is not only that factor used to calculate biomass consumed, but it also depends on pre-existing biomass and burning efficiency (Pathfinder 2007; Zhu et al. 2017). Estimation of burned land surface is required to disclose many ecological and scientific challenges such as understanding disturbance-driven changes in ecosystem function carbon fluxes (Randerson et al. 2012). The burned land cover impacts on the atmospheric chemistry and human health and additionally have effect on the strength of climate-carbon cycle feedbacks ( $\mathrm{N}$ Andela et al. 2017). Wildfires emit around 1.6-2.8 $\mathrm{PgC}_{\text {year }}{ }^{-1}$ into the atmosphere; this amount equals about $20-30 \%$ of present-day fossil fuel burning emission (Kloster et al. 2012).

Remote sensing is an important approach to monitoring wildfires. Remotely observation data were used to estimate burned area (Mangeon et al. 2015). Compared to field-based measurement approaches, remote sensing techniques have many advantages such as coverage of large areas, being noninvasive, collection of data in less accessible regions and cost effectiveness (Leblon et al. 2012). Some disadvantages of this method are optical remote sensing in cloudy conditions, difficulty in observing burned areas that are smaller than the resolution of the sensor and false detection of burned areas by inundation and dark rocks (Tansey et al. 2004).

The Moderate-Resolution Imaging Spectroradiometer (MODIS) is used for the activity of fire product which depends on daily surface reflectance imagery from the Terra and Aqua satellite platforms (Lasko 2019). The MODIS data give diurnal data in 36 spectral bands, and there are three different spatial resolutions (Mangeon et al. 2015). There are many factors that contribute to forest fires, some of them related to climatic condition. Ertugrul et al. (2019) established a relationship between 1977, 1985 and 1986 fire seasons and the climate values in Çanakkale Region in Turkey. The location of fire look out towers analysis as one approach to monitor forest fires in Turkey (Kucuk et al. 2017).

Distribution of vegetated land in Iraq includes forest cover, located in the north and northeast of the country. Other area is divided between agriculture area and pasture. Wheat and barley are the main crops cover the most agriculture area in the country (Malinowski 2002). The most fire accident accrues during hot and dry season. However, forests also suffer from wildfires, man-made and natural disturbances (Rahimi et al. 2020). In many countries, the forest and farmland fire problem has been evaluated and protected; however, many countries have not given attention to the problem of wildfires. Iraq is one such country, which is suffering from wildfires. In this study, we quantitatively estimate the amount of biomass burning from a global burned area product in Iraq. The objective of the research is to determine the trend of burned area in Iraq from 2001 to 2019 and select the main 
climatic factors that contribute to wildfires. The study also investigates at the Governorate scale because the overall country picture is not consistent across the country.

\section{Materials and methods}

\subsection{Study area}

Iraq shares a border with Jordan and Syria in the west, Saudi Arabia and Kuwait in the south, the Islamic Republic of Iran in the east and Turkey in the north as shown in Fig. 1. The area of Iraq is about $438,320 \mathrm{~km}^{2}$. A mountainous area is located on the north and the east of Iraq, where elevations of $3550 \mathrm{~m}$ above sea level are reached. Iraq has also the desert area in the south and the west, which covers around $40 \%$ of all land (Malinowski 2002).

The country consists of eighteen governorates, which are divided into two parts. Erbil, Dohuk and Sulaymaniyah Governorates are gathered in a federal region in the northern part of Iraq, while the other fifteen provinces are located in central and southern Iraq. Farmland in Iraq is estimated at $115,000 \mathrm{~km}^{2}$, which accounted for around $26 \%$ of the total area of the country. The remaining areas are not viable for agricultural use and there are some areas located on the extreme northern border with Turkey and Iran is covered by forest and woodlands. The total area that cultivated in Iraq is about $60,000 \mathrm{~km}^{2}$, of which almost half is located in northern Iraq under rainfed conditions, and permanent grassland covers about 35\% (Al-haboby et al. 2017).

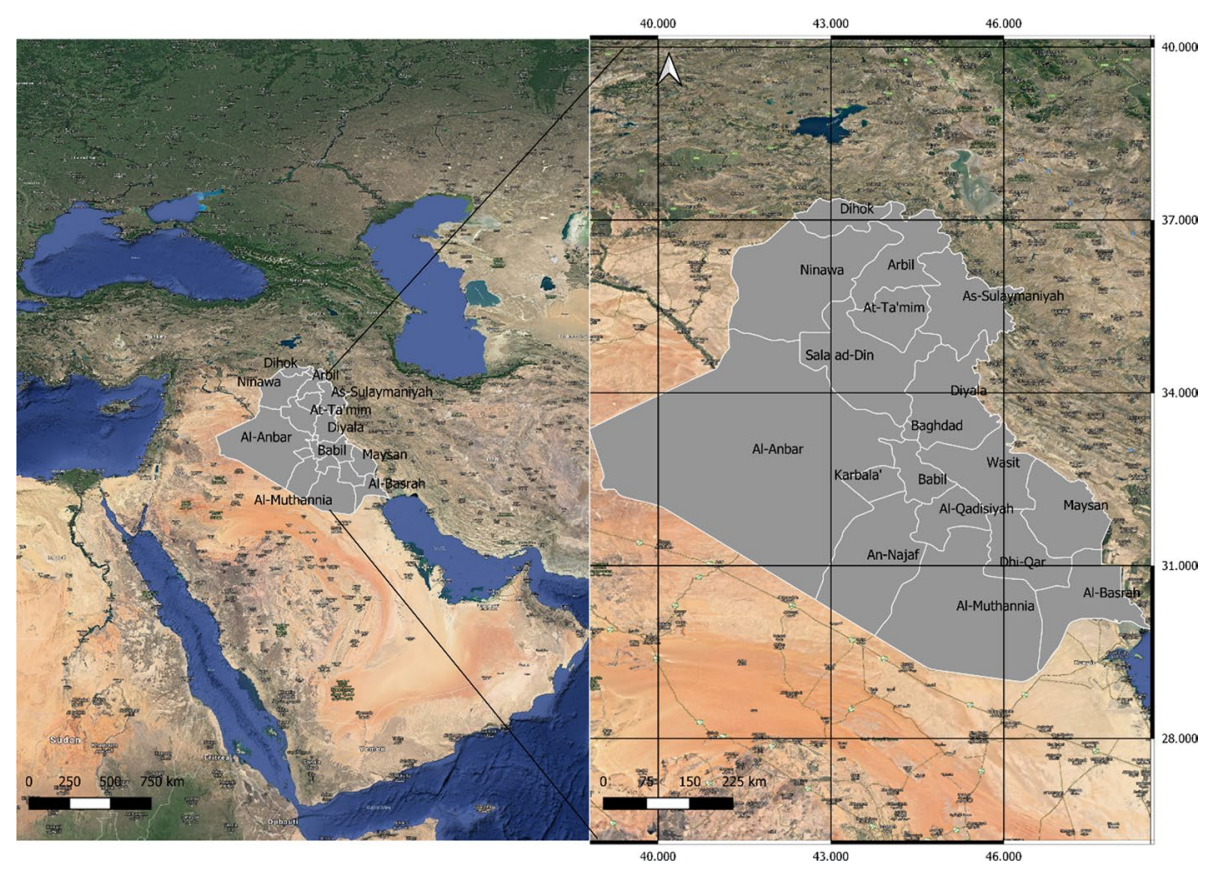

Fig. 1 Location of the study area 
The climate of Iraq is principally subtropical semiarid type, with a Mediterranean Climate in the north and northeastern mountainous area. Precipitation in the study area is seasonal which starts from November to April in the north and northeast of the country (Hameed 2013), while in the middle and south of the country it starts from December to February. Mean annual precipitation is recorded as $216 \mathrm{~mm}$. It starts from $100 \mathrm{~mm}$ in the south and reaches $1200 \mathrm{~mm}$ in the northeast. The temperature in winter is around $16{ }^{\circ} \mathrm{C}$ dropping to $2{ }^{\circ} \mathrm{C}$ at night. The summer season is dry and hot with a shade temperature of $43{ }^{\circ} \mathrm{C}$ during July and August (Metz 1990).

\subsection{Data}

MODIS "MCD64A1" data of burned areas were used in this study (Table 1). Regarding the climatic data, specific humidity was selected from CFSV2 (Saha et al. 2011) and we used ERA5 data (Copernicus Climate Change Service (C3S) 2017) for other climatic elements, namely, air temperature, maximum air pressure, specific humidity, wind speed and total precipitation. Data to each Iraq extracted by use shapefile of countries used from "LSIB 2017: Large Scale International Boundary Polygons, Simplified."

The climatic data and LAI and NDVI indices of the study area were extracted through using Google Earth Engine (GEE) Platform and then downloaded to a local computer. Extracted data were used for analysis and creating graphs. Wind speed is calculated by using Eq. (1) from u component and v component of wind.

$$
\mathrm{ws}=\operatorname{sqrt}\left(\left(u_{-} \mathrm{com} * u_{-} \mathrm{com}\right)+\left(v_{-} \mathrm{com} * v_{-} \mathrm{com}\right)\right)
$$

\subsection{Methodology}

Monthly burned area data came from the MODIS MCD64A1 version 6 burned area product, collected for each year from 2001 to 2019 using Earth Engine Code Editor (Gorelick et al. 2017). "Burned area" product detects post-fire characteristics such as removal of vegetation and ash, while "active fire" products detect fires during the time of overpass of a satellite (modis-fire.umd.edu 2020). In the current research, we preferred to use the first one, which detects the negative effect of the fire on the land such as forest, while the second deals with the energy that release from the fire such as temperature. The study selected the year 2001 as start of study period because "MCD64A1" product in GEE was available from November 2000. Then, "BurnDate" layer of the product was selected and the data were clipped to the shapefile of the Iraqi border. Annual data were prepared based on median of monthly images. Then, burned pixel numbers were extracted for entire study area and each governorate. Finally, burned pixels were converted to areas in $\mathrm{km}^{2}$. Statistical outputs such as yearly trend and trend during the period (trendp) were computed by using Eq. (2), Theil-Sen approach (TSA) in "zyp" package in R (Bronaugh et al. 2009). The significance of the trend was examined by using a Kendall test (Yue et al. 2002) Eq. 3.

$$
b=\operatorname{Median}\left(\frac{x_{j}-x_{l}}{j-l}\right) \quad \forall l<j
$$

where $b$ is the estimation of the slope of the trend and $x_{l}$ is the $l$ th observation. 


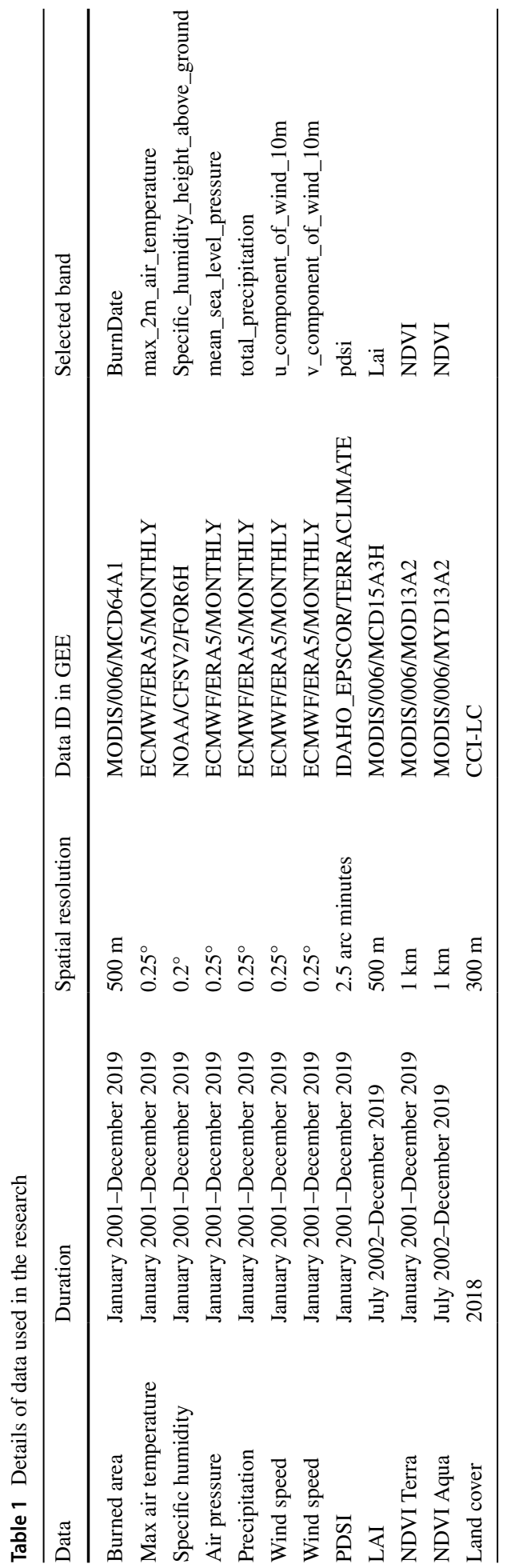




$$
\begin{gathered}
s=\sum_{i=1}^{n-1} \sum_{j=i+1}^{n} \operatorname{sign}\left(x_{j}-x_{i}\right) \\
\operatorname{sign}\left(x_{j}-x_{i}\right)= \begin{cases}1 & \text { if } x_{j}-x_{i}>0 \\
0 & \text { if } x_{j}-x_{i}=0 \\
-1 & \text { if } x_{j}-x_{i}<0\end{cases}
\end{gathered}
$$

where $x_{1}, x_{2} \ldots x_{n}$ represent $\mathrm{n}$ data points, $x_{j}$ represents the data point at time $\mathrm{j}$, and $\mathrm{S}$ is the Mann-Kendall test.

Finally, we assessed relationship between monthly burned areas in Iraq and monthly climatic variables and LAI and NDVI vegetation indices. Pearson correlation coefficient (Eq. 4) was used to display linear relationship. Results of relationship were displayed as scatter plot. $P$ value in the figure demonstrated statistical significance of association. Regression line, confidence interval and $95 \%$ prediction interval were added to the graph.

$$
R=\frac{\sum(x-\bar{x})(y-\bar{y})}{\sqrt{\sum(x-\bar{x})^{2} \sum(y-\bar{y})^{2}}}
$$

where $x$ is variables and $y$ is monthly burned areas. The $R$ value near +1 means a strong positive relationship; a value near -1 demonstrates a strong negative relationship. Zero degree means non-relationship between variables.

\section{Results}

\subsection{The trend of fires in Iraq}

Spatial and temporal variability in burned area is considered in the north, northeast, south and southeast regions (Fig. 2). Although fire and burnt areas can be condensed or even absent from the west and southwest, the rate of fires and burned areas had a gradual increase of about $1363 \mathrm{~km}^{2}(p=0.034)$ from 2001 to 2019 , especially in the last years. The study found that the trend of burned area increases in study area at different extents between the years 2001 to 2019 . There was a total fire site escalation by the rate of $71.74 \mathrm{~km}^{2}$ per year in the period of the study.

During the period of the study, the highest amount of burned areas $\left(16,180 \mathrm{~km}^{2}\right)$ occurred only in 2019, while the smallest quantity of burned areas occurred during 2012 $\left(508 \mathrm{~km}^{2}\right)$. The average of burned area in Iraq from 2001 to 2018 was $2010 \mathrm{~km}^{2}$ per year. In other words, only in 2019 burned areas increased to around eight times of average of burned amount as a reason for numerous crop field fire incidents (Fig. 3).

Some detected burned areas in Iraq were cross-border and related to fires in neighboring countries of Iraq. Cross-border burned areas in Iraq usually occurred in the east part with Iran and in the north and northwest with Turkey and Syria. The reason is these parts are mostly covered by forest, grass or agriculture. In contrast, cross-border fires not occurred in the west and south part of Iraq, which located Syria, Jordan, Saudi Arabia and Kuwait in these sides of the border. The reason behind it is that mostly these parts of the country are desert. 
Fig. 2 Spatial distribution of total fires in Iraq from 2001 to 2019

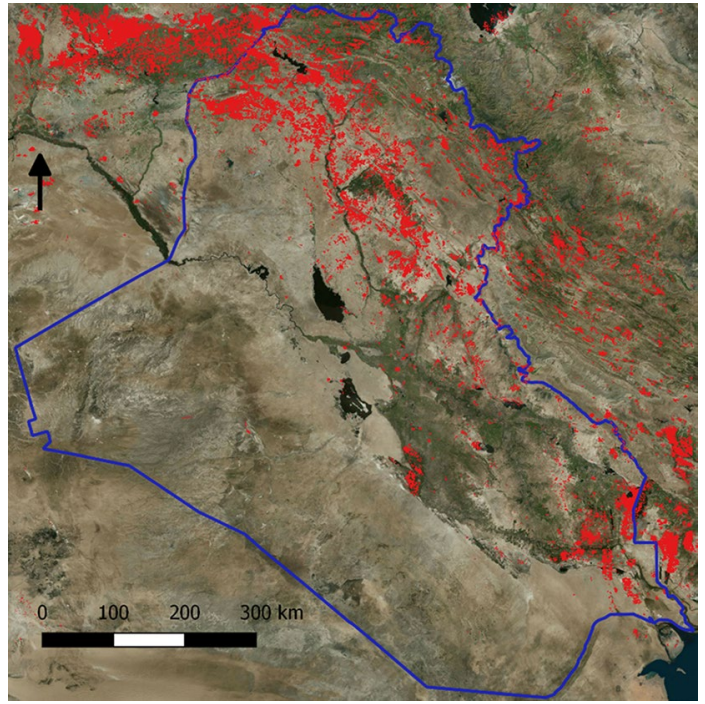

Fig. 3 The trend of burned areas $\left(\mathrm{km}^{2}\right)$ in Iraq from 2001 to 2019

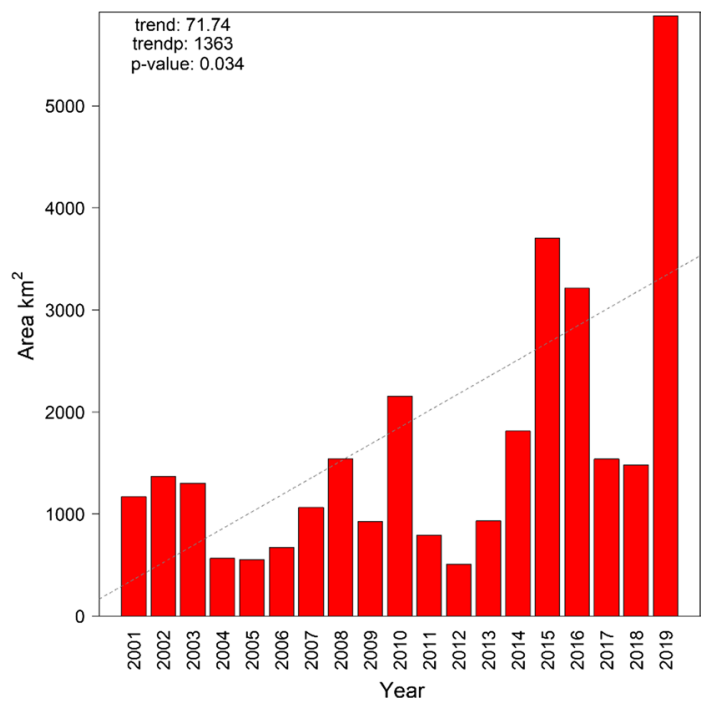

During 2001, cross-border fires occurred between Iraq and Iran close to "Khanaqin" and in the north part, burned area crossed border with Syria near "Mahmudia." During 2007, a cross-border fire occurred in the east of Iraq close to "Maidan District." During 2012, also cross-border fires were recorded in the north part with Syria near "Walid" border. During 2013, some of cross-border fires were recorded with Iran near to "Ahwaz" province in Iran. During 2015, cross-border burned area was detected in the north part of the country near Turkey border in "Amedi." During 2017, a big cross-border burned area was detected with Iran near "Halabja." During 2019, burned area was detected in "Bldrwz" district with Iran border and the northwest near "Iahribia" border close to "Hasaka" city in Syria. 


\subsection{The trend of fires in Iraqi Governorates}

The average annual fires had increased in fifteen out of eighteen Governorates. The highest increased trends during the period of the study were found in Missan $\left(240.7 \mathrm{~km}^{2}\right.$, $p=0.015)$, Sulaymaniyah $\left(188.7 \mathrm{~km}^{2}, p=0.112\right)$ and Erbil Governorates $\left(128.8 \mathrm{~km}^{2}\right.$, $p=0.096)$. In contrast, in Kerbala and Muthanna Governorates burned area did not increase and in Basrah the trendp was negative $\left(-15.8 \mathrm{~km}^{2}, p=0.939\right)$. It means the governorate saw a decrease in fire event rates and burnt areas (Fig. 4e). During 2019, the most increase of burned areas occurred in Ninewa Governorate. It increased from $284 \mathrm{~km}^{2}$ as average to $6822 \mathrm{~km}^{2}$. In SalahAlDin, it increased from average of $60 \mathrm{~km}^{2}$ increased to $2587 \mathrm{~km}^{2}$ and the third highest increase of burned areas in 2019 occurred in Diyala Governorate (Fig. 5).

During nineteen years of the study period, Ninewa, Sulaymaniyah and SalahAlDin Governorates faced most burned areas with 29, 9.1 and $8.9 \%$, respectively. In contrast, fires with a contribution of less than 1\% occurred in Anbar, Baghdad, Muthanna, Babil and Kerbala Governorates (Fig. 6).

(a) Ninewa

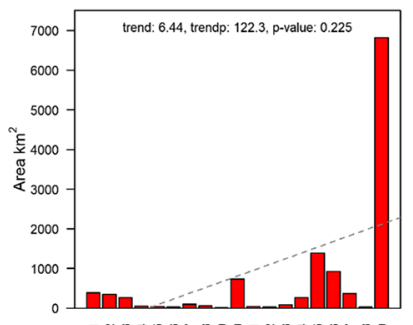

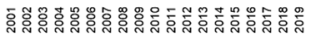

(d) SalahAIDin

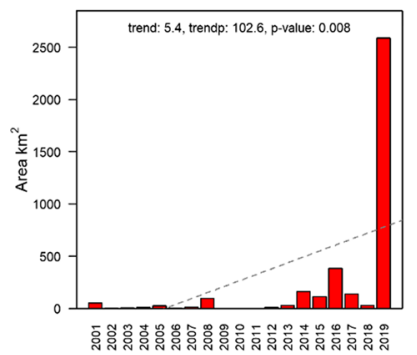

(g) Diyala

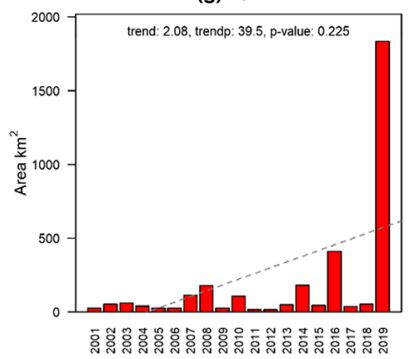

(b) Sulaymaniyah

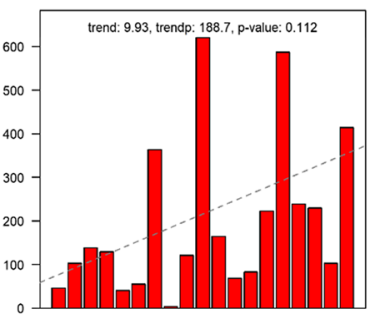

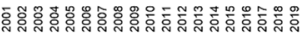

(e) Basrah

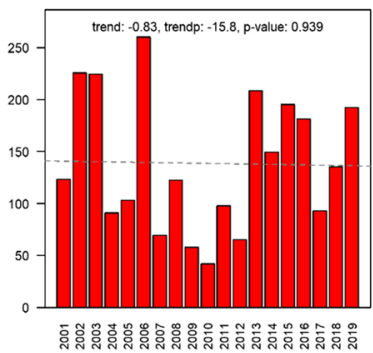

(h) Dahuk

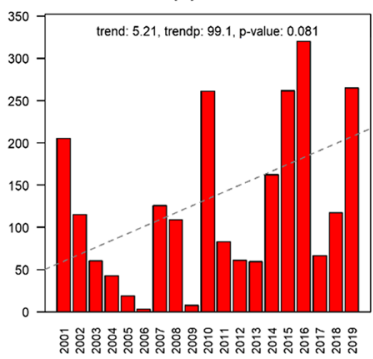

(c) Missan

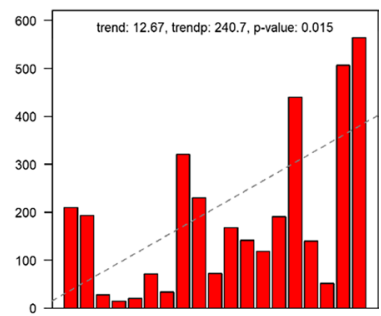

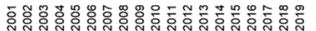

(f) Kirkuk

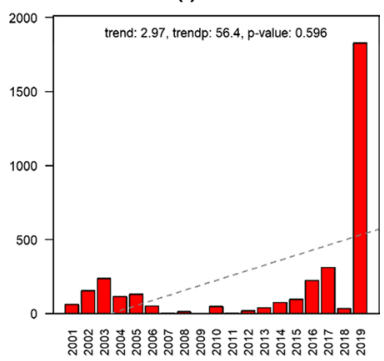

(i) Erbil

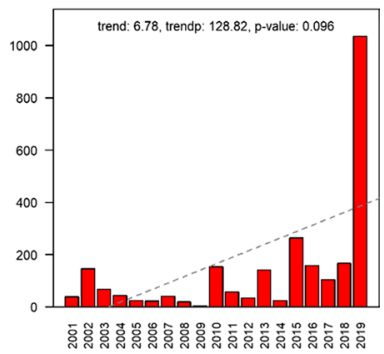

Fig. 4 The trend of burned areas $\left(\mathrm{km}^{2}\right)$ in Iraqi Governorates from 2001 to 2019 


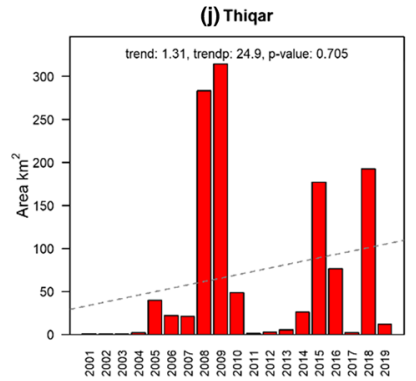

(m) Wassit

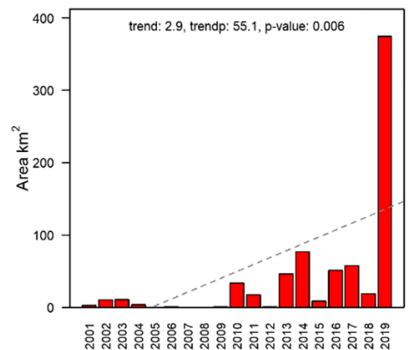

(p) Baghdad

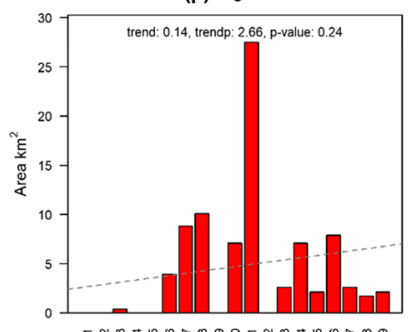

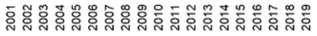

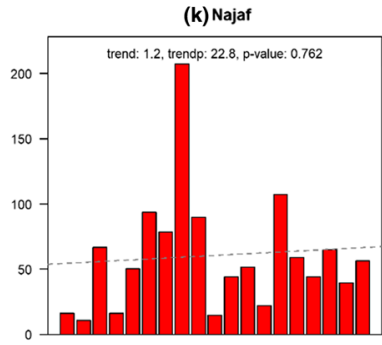

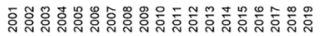

(n) Anbar

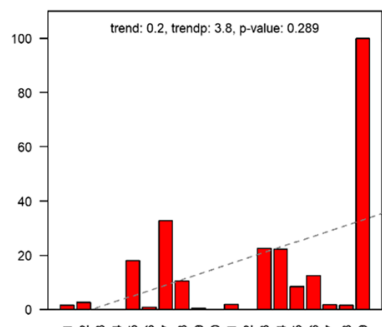

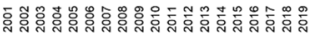

(q) Muthanna

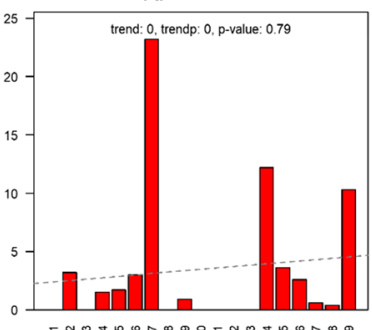

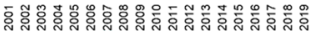

(I) Qadissiya

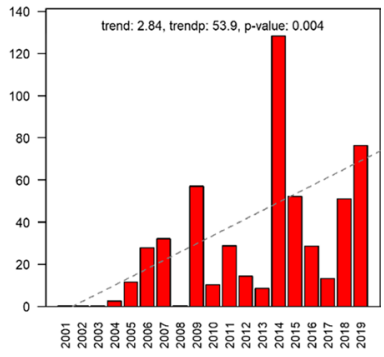

(o)Babil

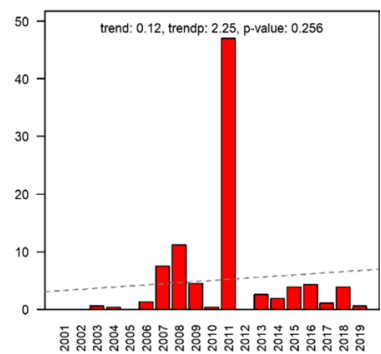

(r) Kerbala

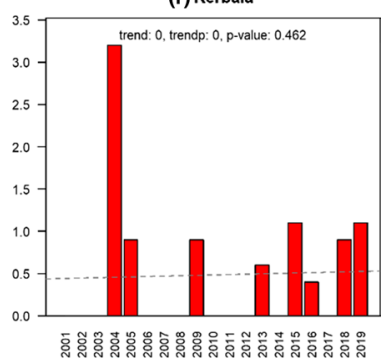

Fig. 4 (continued)

\subsection{Burned areas in Iraq based on land cover classes}

Figure 7 shows 21 land cover classes in Iraq based on CCI-LC 2018 data. Table 2 shows burned areas in $\mathrm{km}^{2}$ for each class in Iraq during 2019. In the table, the first highest class, which contains burned area with $8553 \mathrm{~km}^{2}$ of burned area, is "Bare areas." Burned areas in this class are mostly located in Nainawa, SalahAlDin and Diyala Governorates. The reasons for detected burned areas in this class may be use of some areas changed and the incorrect class descriptor in some cases as Fig. 8 demonstrates. Figure 9 displays the correct detection of burned area in Iraq by MODIS through comparing Landsat images before and after the fire. The second highest burned area class is "Cropland, rainfed" with $4366 \mathrm{~km}^{2}$. The third and fourth classes in order of containing highest burned area are "Herbaceous cover" and "Mosaic natural vegetation" classes with 1866 and $203 \mathrm{~km}^{2}$, respectively. 


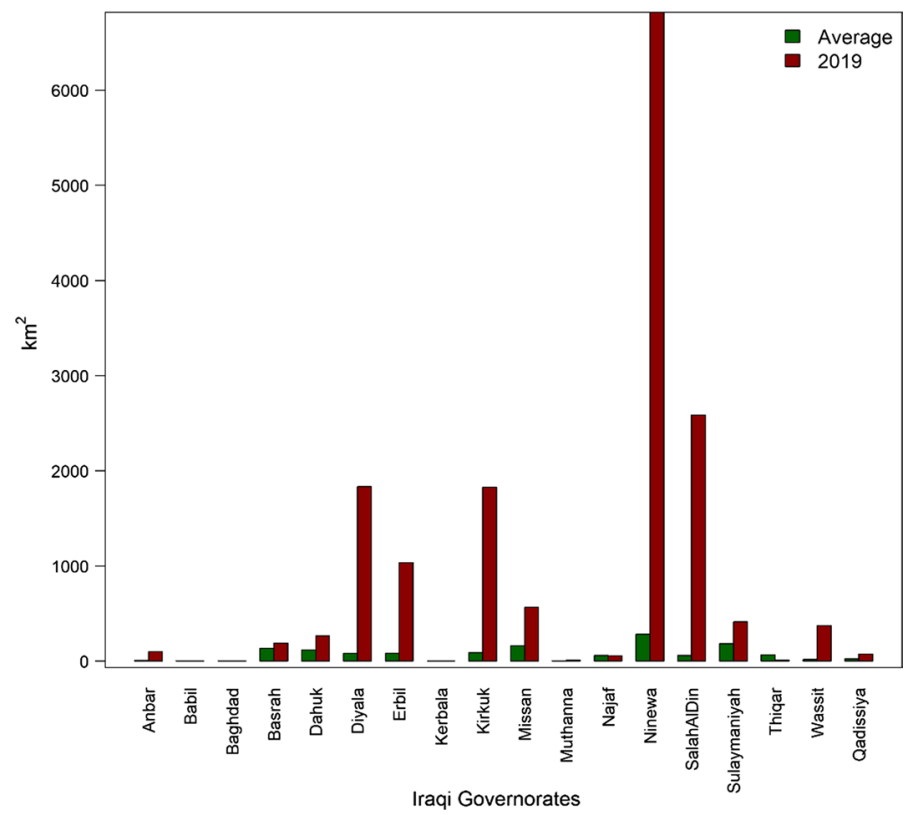

Fig. 5 Comparison of burned areas in 2019 to an average of 2001 to 2018 for each Iraqi Governorates

\subsection{Relationship between monthly burned area and variables}

In Fig. 10, by using "208" points, each of which represents a month from January 2001 to December 2019, Pearson correlation coefficient is used to assess linear relationship between monthly burned areas and climatic variables and vegetation indices that represent fuel of fire. Figure 9 demonstrates that a significant ( $p$ value $<0.001)$ weak inverse relationship confirmed between monthly burned areas and sea level air pressure and total precipitation. The effect of low air pressure on decrease in burned areas is perhaps explained by low oxygen density in this condition which is necessary for fire. Low burned areas are associated with high amount of precipitation and air pressure. Relationship of burned areas is positive with maximum air temperature, specific humidity, Palmer Drought Severity Index (PDSI), wind speed. It means high wind and maximum temperatures lead to an increasing amount of burned areas in the country. The highest inverse Pearson correlation appeared with PDSI $(R=0.29 ; p$ value $<0.001)$ and then both max air temperature and wind speed $(R=0.27 ; p$ value $<0.001)$. Significant relationship is not found between amount of burned area and LAI and NDVI indices because burned areas occurred in different vegetation conditions in Iraq. 


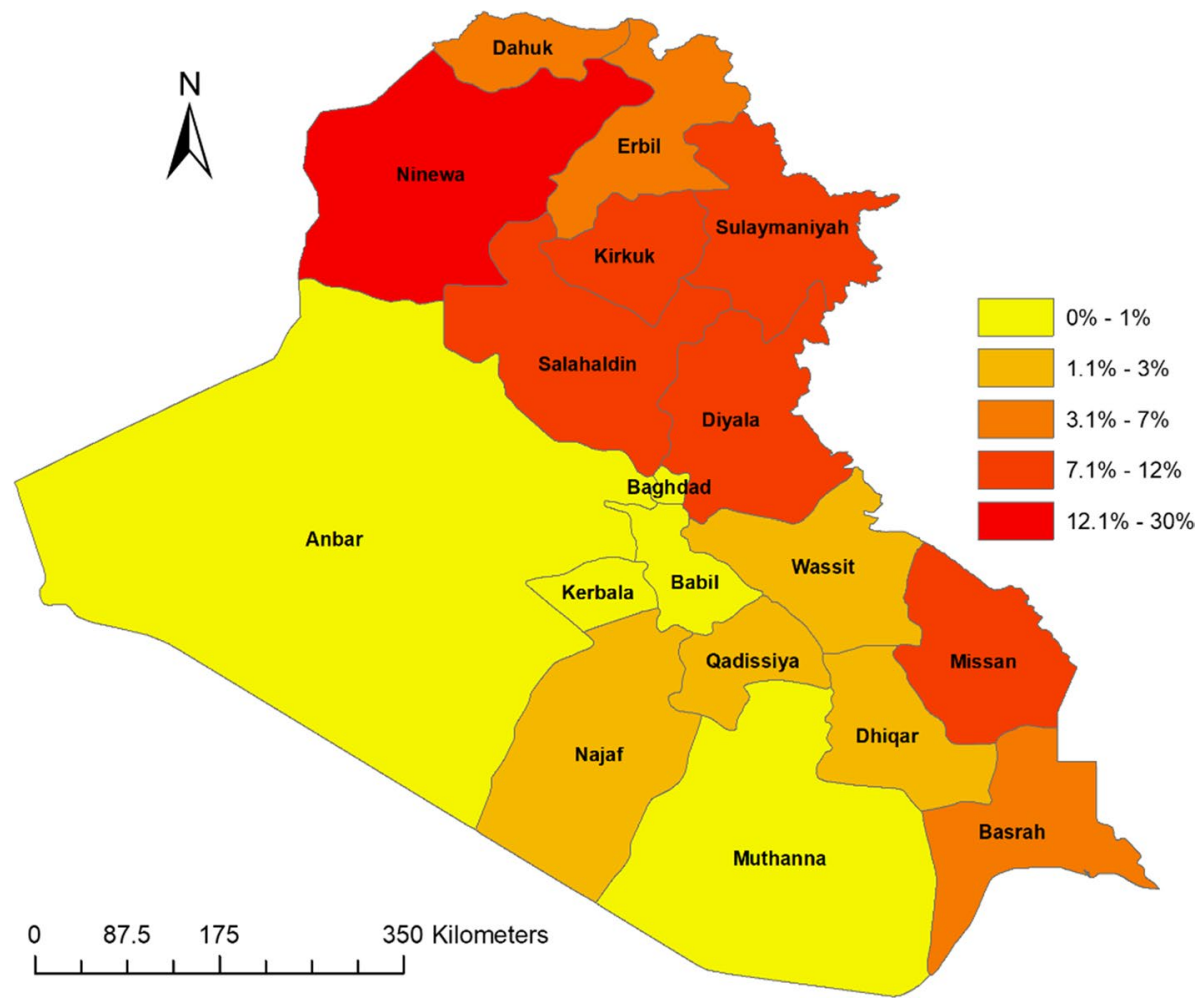

Fig. 6 Percentage of the burned area of each governorate during period 2001 to 2019

\section{Discussion}

Over the last two decades, fires are more recurrent and the amount of burned area increased per year in the northeast and southeast of Iraq. However, the Muthanna, Kerbala and Basrah Governorates did not display an increase. One possible reason is having security conditions in the southern governorates, and these governorates are mostly desert and have a slight vegetation and agriculture. The study findings of increasing trends in the rate of fires and burned areas are comparable to results of the other studies in different places. For instance, Westerling (2016) and Dennison et al. (2014) observed that tendencies in wildfire and burnt areas were most significant in all forest kinds from 1984 to 2006.

The results of this study have determined that the least fire-affected areas were in the western, center and southwestern parts of the country as the land is typically barren and without vegetation. These areas are Babil, Baghdad, Kerbala and Muthanna Governorates. Contrastingly, the areas, which experienced the most fire events, were located in the northeast and north of Iraq. These areas had forested mountainous areas and agricultural lands. These areas were Ninawa, Kirkuk, Sulaymaniyah and SalahAlDin Governorates. In particular, the Ninawa experienced $29 \%$ of entire burned areas in Iraq during the study period. This outstanding fire rates can be a result of various wheat farms that were burnt by various means throughout the study period. Also, drought and hot temperatures are major 


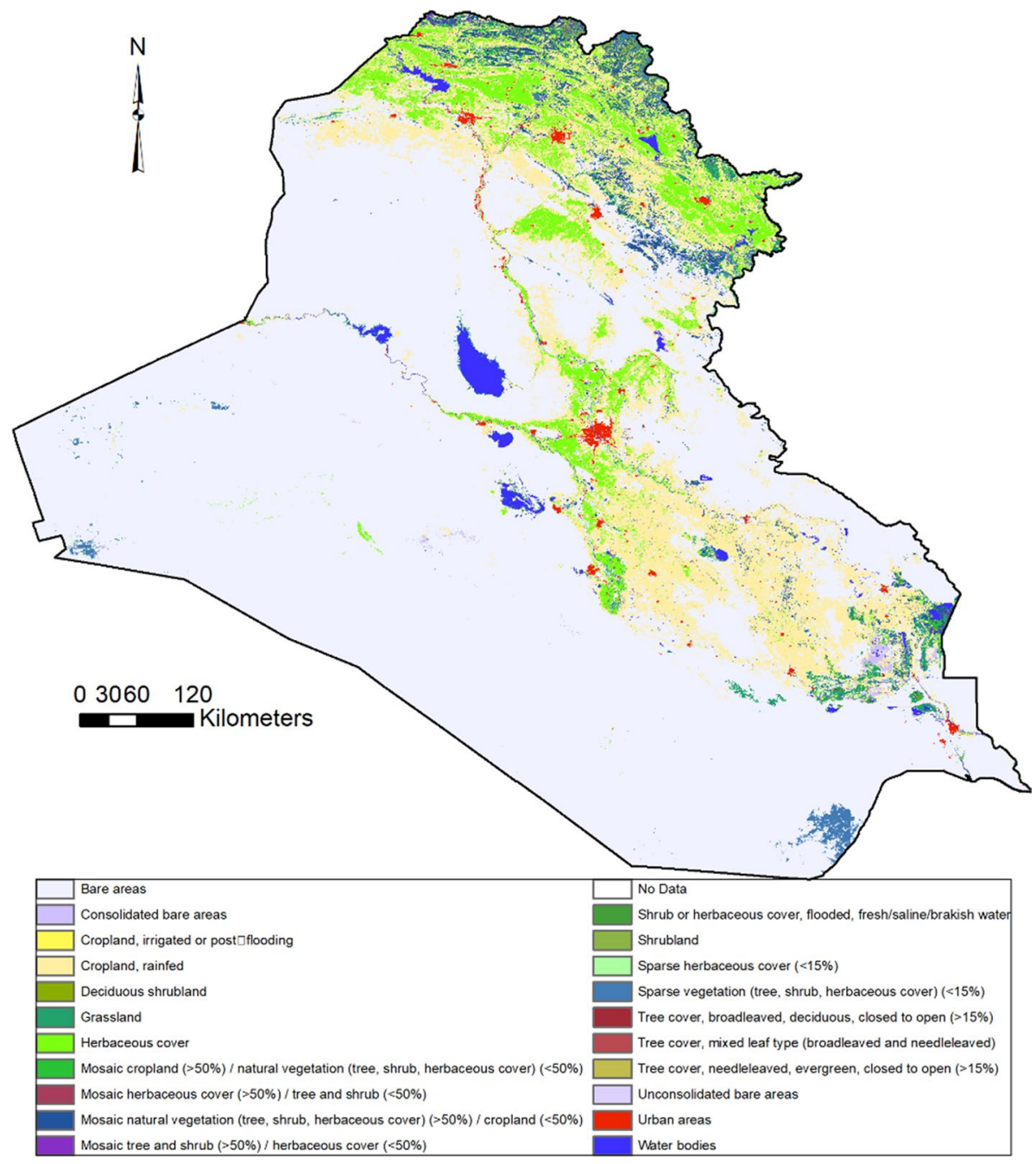

Fig. 7 Land cover of Iraq based on "CCI-LC" 2018 data

reasons for the ignition of most fires. Iraq experiences high temperatures at the end of spring and during summer, which encouraged many fire breakouts in the areas. The detection of burned area is synchronous with crop harvesting periods. Furthermore, due to the deficiency of awareness among population, some of these fires might have begun. During 2019, Ninawa, SalahAlDin and Diyala Governorates presented great area burned. Whereas more burned areas associated with high maximum temperature and low precipitation, climate change will worsen this problem in the future.

Besides, one of the most significant factors that affect fire rates in the study area is the political and security aspect. After 2014, the combating with the Islamic State of Iraq and Syria (ISIS) group resulted in the destruction of many areas, especially the north and northwestern places of the study area which resulted in the loss and burning of many agricultural lands. The land ownership conflict between different nationalities in Iraq is another 
Table 2 Burned areas in Iraq for each land cover classes during 2019

\begin{tabular}{lr}
\hline Classes & Area $\left(\mathrm{km}^{2}\right)$ \\
\hline Cropland, rainfed & 4366 \\
Herbaceous cover & 1866 \\
Cropland, irrigated or post-flooding & 3 \\
Mosaic cropland ( $>50 \%)$ /natural vegetation (tree, shrub, herbaceous cover) $(<50 \%)$ & 91 \\
Mosaic natural vegetation (tree, shrub, herbaceous cover) $(>50 \%) /$ cropland $(<50 \%)$ & 203 \\
Tree cover, broadleaved, deciduous, closed to open $(>15 \%)$ & 0 \\
Tree cover, needle-leaved, evergreen, closed to open $(>15 \%)$ & 0 \\
Tree cover, mixed leaf type (broadleaved and needle-leaved) & 0 \\
Mosaic tree and shrub $(>50 \%) /$ herbaceous cover $(<50 \%)$ & 5 \\
Mosaic herbaceous cover $(>50 \%) /$ tree and shrub $(<50 \%)$ & 0 \\
Shrubland & 20 \\
Deciduous shrubland & 1 \\
Grassland & 46 \\
Sparse vegetation (tree, shrub, herbaceous cover) $(<15 \%)$ & 59 \\
Sparse herbaceous cover $(<15 \%)$ & 4 \\
Shrub or herbaceous cover, flooded, fresh/saline/brackish water & 0 \\
Urban areas & 15 \\
Bare areas & 8553 \\
Consolidated bare areas & 3 \\
Unconsolidated bare areas & 0 \\
Water bodies & 18 \\
\hline
\end{tabular}

reason that led to the incident of burning fields, especially during 2018 and 2019. The increase in the rate of burned area will eventually have a negative effect on the environment and human society through risks of increasing air pollution, decreasing biodiversity and decreasing green space within forests in the country. Fires in Iraq should continue to be monitored, and the burned area statistics should be reported to relevant agencies responsible for planning, health and development.

\section{Conclusions}

Wildfire leads to destroying biomass that could be calculated by estimating burned areas. Monitoring the trend of the burned areas and assessing factors that contribute to wildfires is an important criterion of earth observation on the global and local scales. The study found that the highest amount of burned areas were located in northeast and north of Iraq. The trend of burned areas in Iraq was an increase of $71.7 \mathrm{~km}^{2}$ per year during the study period. In 2019, burned areas increased to around eight times compared to the yearly average. One of the highest classes, which contain burned area, is "Cropland, rainfed." Among assessed climatic elements, high air temperature and wind speed are the main factors that contribute to increasing burned areas, while high precipitation and air pressure lead to a reducing amount of burned areas. 
Fig. 8 Example of burned cultivated land in Nainawa Governorate classified under "Bare areas" in CCI-LC 2018
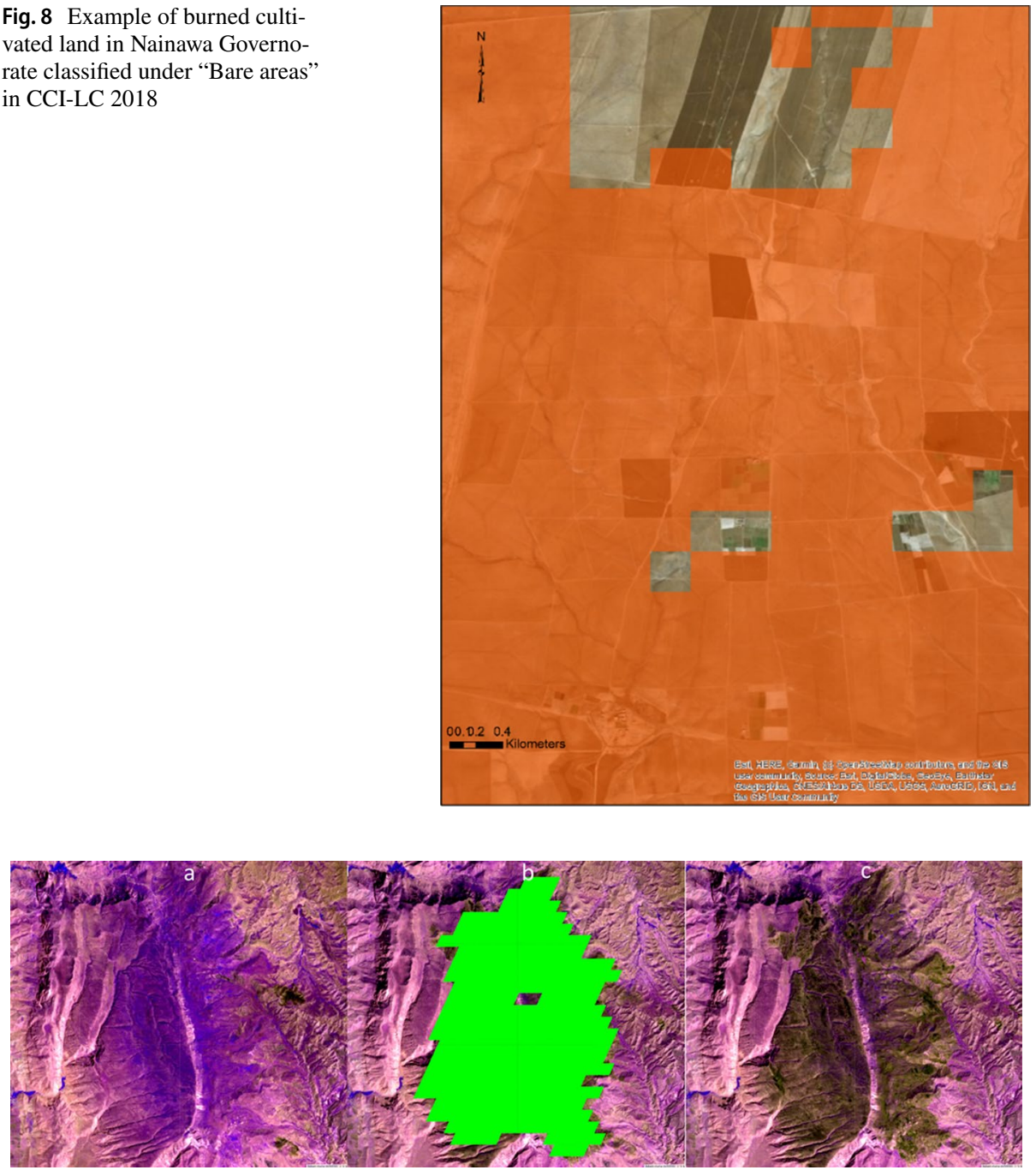

Fig. 9 Example of correct detected burned area by MODIS in Belula, Iraq, during July 2018. a Landsat image before the fire, $\mathbf{b}$ detected burned area by MODIS, c Landsat image after the fire displays effect of burned area

The rapid increase of fires in the country as a result of burn crop field residues will lead to worsening air pollution and likely decrease biomass in the future. While more burned areas associated with high maximum temperature and low precipitation, climate change will worsen this problem in the future. Increasing burned areas in the country lead to increase in air pollution and decrease in biomass area. As the highest portion of burned areas occurred in rainfed cropland class, it has negative effects on food security in the country.

The research has limitations which some of them related to the data used in the observation such as false detection in the dark pixels and not detect small fires because of the 
Interval $-95 \%$ confidence $-95 \%$ prediction

(a)

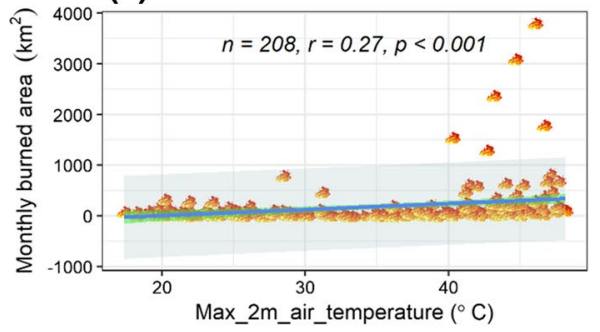

(c)

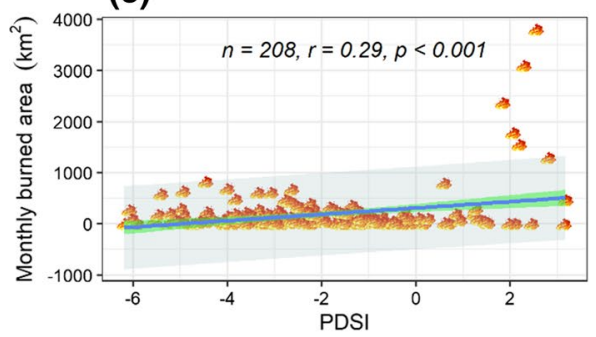

(e)

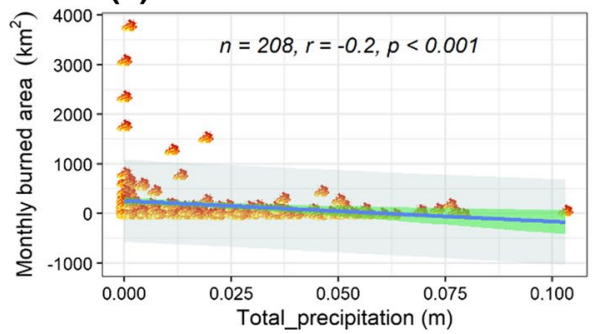

(g)

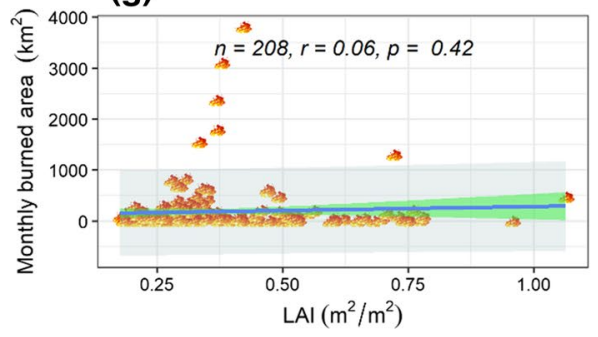

(b)

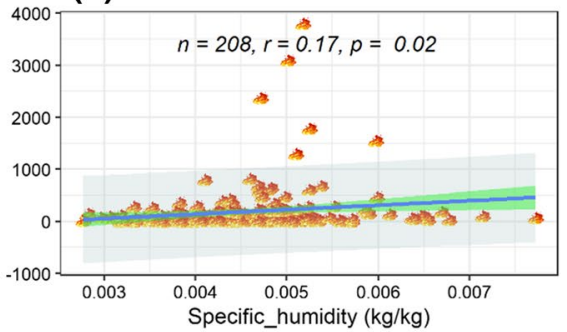

(d)

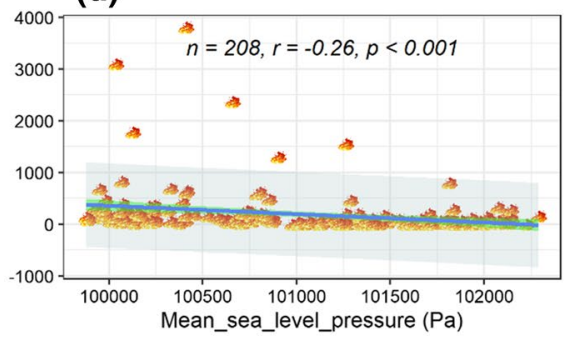

(f)

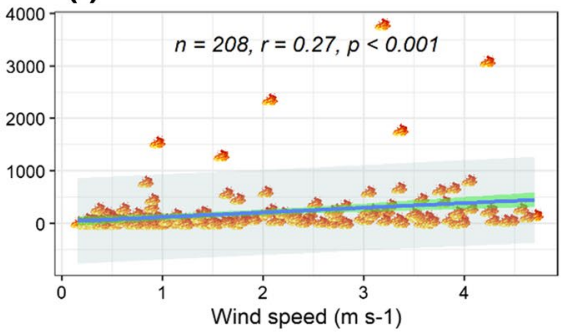

(h)

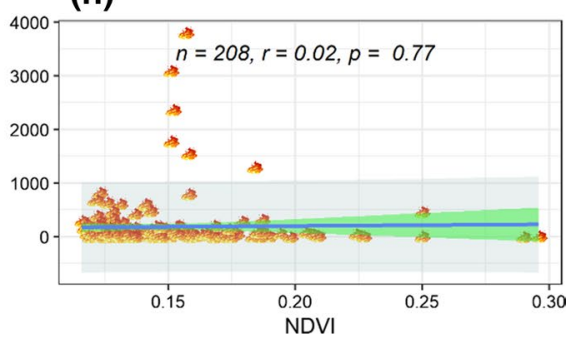

Fig. 10 Relationship between monthly burned area in Iraq and monthly maximum air temperature above $2 \mathrm{~m}$ (a), specific humidity height above ground (b), Palmer Drought Severity Index (c), sea level pressure (d), total precipitation (e), wind speed at $10 \mathrm{~m}(\mathbf{f})$, LAI (g) and NDVI (h). Each plot represents a month from 2001 to 2019

moderate resolution of the MODIS product compare to "PROBA-V 330 m" burned area product or event products from Landsat or Sentinel-2. Other limitations are related to lack of availability of ground measurements of the burned area by the government to compare with the remotely sensed estimate to establish the accuracy of the product. More research 
should be performed to better understand factors of increasing burned areas in Iraq by taking into account the socioeconomic situation and the reduction in agricultural fires with increased mechanization.

Author contributions AR contributed to data curation; AR, GRFI and HMH were involved in the formal analysis; AR contributed to methodology; AR contributed to resources; KT supervised; AR contributed to visualization; AR, GRFI, HMH and KT were involved in writing and original draft preparation; AR, GRFI, $\mathrm{HMH}$ and $\mathrm{KT}$ were involved in writing and review and editing.

Funding This research received no external funding.

\section{Compliance with ethical standards}

Conflict of interest The authors declare no conflict of interest.

Open Access This article is licensed under a Creative Commons Attribution 4.0 International License, which permits use, sharing, adaptation, distribution and reproduction in any medium or format, as long as you give appropriate credit to the original author(s) and the source, provide a link to the Creative Commons licence, and indicate if changes were made. The images or other third party material in this article are included in the article's Creative Commons licence, unless indicated otherwise in a credit line to the material. If material is not included in the article's Creative Commons licence and your intended use is not permitted by statutory regulation or exceeds the permitted use, you will need to obtain permission directly from the copyright holder. To view a copy of this licence, visit http://creativecommons.org/licenses/by/4.0/.

\section{References}

Al-haboby, A., Breisinger, C., \& El-hakim, A. H. (2017). Agriculture for development in Iraq? Estimating the impacts of achieving the agricultural targets of the national development plan 2013-2017 on economic growth, incomes, and gender equality (May 2014).

Andela, N., Morton, D. C., Giglio, L., Chen, Y., Van Der Werf, G. R., Kasibhatla, P. S., et al. (2017). A human-driven decline in global burned area. Science, 1362(June), 1356-1362.

Andela, N., \& Van Der Werf, G. R. (2014). Recent trends in African fires driven by cropland expansion and El Niño to La Niña transition. Nature Climate Change, 4(September), 791-795. https://doi. org/10.1038/NCLIMATE2313.

Bronaugh, D., Werner, A., \& Bronaugh, M. D. (2009). Package 'zyp.' CRAN Repository.

Copernicus Climate Change Service (C3S). (2017). ERA5: Fifth generation of ECMWF atmospheric reanalyses of the global climate. In Copernicus Climate Change Service Climate Data Store (CDS). https ://cds.climate.copernicus.eu/cdsapp\#!/home. Retrieved April 22, 2020.

Dennison, P. E., Brewer, S. C., Arnold, J. D., \& Moritz, M. A. (2014). Large wildfire trends in the western United States, 1984-2011. Geophysical Research Letters, 41(8), 2928-2933.

Ertugrul, M., Ozel, H. B., Varol, T., Cetin, M., \& Sevik, H. (2019). Investigation of the relationship between burned areas and climate factors in large forest fires in theÇanakkaleregion. Environmental Monitoring and Assessment, 191(12), 737.

Gorelick, N., Hancher, M., Dixon, M., Ilyushchenko, S., Thau, D., \& Moore, R. (2017). Google Earth Engine: Planetary-scale geospatial analysis for everyone. Remote Sensing of Environment, 202, 18-27. https://doi.org/10.1016/j.rse.2017.06.031.

Hameed, H. (2013). Water harvesting in Erbil Governorate, Kurdistan region, Iraq: Detection of suitable sites using geographic information system and remote sensing. Student Thesis Series INES.

Kloster, S., Mahowald, N. M., Randerson, J. T., Lawrence, P. J., \& Sciences, A. (2012). The impacts of climate, land use, and demography on fires during the 21 st century simulated by CLM-CN. Biogeosciences, 10, 509-525. https://doi.org/10.5194/bg-9-509-2012.

Kucuk, O., Topaloglu, O., Altunel, A. O., \& Cetin, M. (2017). Visibility analysis of fire lookout towers in the Boyabat State Forest Enterprise in Turkey. Environmental Monitoring and Assessment, 189(7), 329. https://doi.org/10.1007/s10661-017-6008-1. 
Lasko, K. (2019). Incorporating Sentinel-1 SAR imagery with the MODIS MCD64A1 burned area product to improve burn date estimates and reduce burn date uncertainty in wildland fire mapping Incorporating Sentinel-1 SAR imagery with the MODIS. Geocarto International. https://doi.org/10.1080/10106 049.2019.1608592.

Leblon, B., Bourgeau-Chavez, L., \& San-Miguel-Ayanz, J. (2012). Use of remote sensing in wildfire management. Sustainable Development-Authoritative and Leading Edge Content for Environmental Management. https://doi.org/10.5772/45829.

Malinowski, J. C. (2002). Iraq: A geography. United States Military Academy, West Point Department of Geography \& Environmental Engineering, Building 600, West Point, New York 10996. https://eric. ed.gov/?id=ED476013. Retrieved November 20, 2019.

Mangeon, S., Field, R., Fromm, M., Mchugh, C., \& Voulgarakis, A. (2015). Satellite versus ground-based estimates of burned area: A comparison between MODIS based burned area and fire agency reports over North America in 2007. SAGE, 10, 10. https://doi.org/10.1177/2053019615588790.

Metz, H. C. (1990). Iraq, a country study.

Miller, J. D., \& Safford, H. (2012). Trends in wildfire severity: 1984 to 2010 in the Sierra Nevada, Modoc Plateau, and southern Cascades, California, USA. Fire Ecology, 8(3), 41-57.

modis-fire.umd.edu. (2020). MODIS active fire and burned area products: Burned Area. http://modis-fire. umd.edu/ba.html. Retrieved May 30, 2020.

Pathfinder, N. (2007). Global spatial patterns and temporal trends of burned area between 1981 and 2000 using. Global Change Biology. https://doi.org/10.1111/j.1365-2486.2006.01268.x.

Rahimi, I., Azeez, S. N., \& Ahmed, I. H. (2020). Mapping forest-fire potentiality using remote sensing and GIS, case study: Kurdistan Region-Iraq. In A. Al-Quraishi \& A. M. Negm (Eds.), Environmental remote sensing and GIS in Iraq (pp. 499-513). New York: Springer.

Randerson, J. T., Chen, Y., Van Der Werf, G. R., Rogers, B. M., \& Morton, D. C. (2012). Global burned area and biomass burning emissions from small fires. Journal of Geophysical Research: Biogeosciences, 117(December), 10. https://doi.org/10.1029/2012JG002128.

Saha, S., Moorthi, S., Wu, X., Wang, J., Nadiga, S., Tripp, P., et al. (2011). NCEP climate forecast system version 2 (CFSv2) 6-hourly products. Research Data Archive at the National Center for Atmospheric Research, Computational and Information Systems Laboratory.. https://doi.org/10.5065/D61C1TXF.

Tansey, K., Grégoire, J.-M., Stroppiana, D., Sousa, A., Silva, J., Pereira, J. M., et al. (2004). Vegetation burning in the year 2000: Global burned area estimates from SPOT VEGETATION data. Journal of Geophysical Research: Atmospheres. https://doi.org/10.1029/2003JD003598.

Westerling, A. L. (2016). Increasing western US forest wildfire activity: sensitivity to changes in the timing of spring. Philosophical Transactions of the Royal Society B: Biological Sciences, 371(1696), 20150178.

Yue, S., Pilon, P., \& Cavadias, G. (2002). Power of the Mann-Kendall and Spearman's rho tests for detecting monotonic trends in hydrological series. Journal of Hydrology, 259(1-4), 254-271.

Zhu, C., Kobayashi, H., Kan, Y., \& Saito, M. (2017). Size-dependent validation of MODIS MCD64A1 burned area over six vegetation types in boreal Eurasia: Large underestimation in croplands. Scientific Reports. https://doi.org/10.1038/s41598-017-03739-0.

Publisher's Note Springer Nature remains neutral with regard to jurisdictional claims in published maps and institutional affiliations. 